\title{
Gastronomic tourism - stages and evolution
}

\author{
Bogdan Gabriel NISTOREANU \\ The Bucharest University of Economic Studies, Bucharest, Romania \\ bogdan.nistoreanu@fabiz.ase.ro \\ Liliana NICODIM \\ “Ovidius" University Constanta, Romania \\ nicodimlili@yahoo.com \\ Dan Mihnea DIACONESCU \\ The Bucharest University of Economic Studies, Bucharest, Romania \\ dmdiaco@gmail.com
}

\begin{abstract}
On a worldwide level, the dimension of tourism has been sustained and amplified by globalisation. This has facilitated not just easier travel, but also the internationalisation of food from the national kitchens. One of the interesting segments of the immaterial regional cultural heritage is the local gastronomic arts. Each destination has its own cultural vision linked to the area, region, and country which generate corresponding gastronomic identities. The link between local cuisine and national identity is deeply rooted in all ethnicities because food has forever been central to the day to day rituals. A distinctive trait of many cultures is given by the type of food and drinks we associate with them. Currently, many of these are available outside the borders, globalisation being largely responsible to the spread of food and drinks beyond the traditional cultural borders: Mexican and Italian food are very popular in the USA, Indian food in Great Britain, Chinese in the whole world. That is why local gastronomy is considered as being a vital part of culture and community and this is the reason for which it must be kept and protected. The gastronomy is an attribute of the identity of a destination: countries are usually characterised by one or two culinary plates, considered to be emblematic for the nation just like the national flag.
\end{abstract}

Keywords: tourism, gastronomic tourism, sustainable tourism, gourmet tourism.

\section{Introduction to gastronomic tourism}

There is few historic research linked to the beginning of the culinary arts. The origins of the cuisine can be found in the period in which the human being managed to dominate the fire, over five thousand years ago. This discovery has been a fundamental one for the development of the first culinary activities, allowing for the consumption of cooked food. It is believed that Archestratus of Gela (Sicily), which has lived in the IV century before Christ, is the first author which has modelled the concept of "gastronomy" in his work The Art of High Living. The first basic study of gastronomy is probably the essay called The physiology of taste (Physiologie du goût) published by Jean Anthelme BrillatSavarin in the year 1825, which deals with the relationship between senses and food. The knowledge gathered regarding the technique, proportions, plate building, a true culinary savoir-faire has been offered to future generations with the first recipes whose traces have been discovered in documents dating from 1700 B.C.

of the more recent reference books, we can mention "The book of hunt cuisine" by Taillevent (1486) and "The great cook book" (1500) (Raoult-Wack, 2007, p. 26).

Beginning with the second half of the $19^{\text {th }}$ century, we can talk about gastronomic tourism, meaning the possibility of knowing the values of the cultural culinary space to which we belong, as well as of the creations of other cultures and religions. Hall and Mitchell (2005b) argue that the propensity for a successful combination of food, wine 
and tourism has been known since the eighteenth century with the opening of the first restaurants (Hall \& Mitchell, 2005b). In 1786, the term restaurateur / innkeeper appeared for the first time in a text of the law.

It seems that the first restaurateur was a certain Boulanger, which served in his diner soup with meat, "bouillons". The first wine and food circuits took place in Germany at the end of 1920, and tourists were encouraged to taste a wide variety of local produce while visiting the region. The progress of democratic ideas, scientific and technical discoveries have made food easier to obtain. Gastronomy was thus becoming more and more accessible to the great majority.

Since the 1960s, interest in culinary activities has grown, as evidenced by the mass of cookbooks and culinary journals published or by the increase in the number of culinary shows. The 1970s have been marked by people's desire for novelty, which has led to greater receptivity and openness to tasting and information about other traditional cuisines. Also, changing the role of women in society has meant that cooking should go from a compulsory domestic task for women to a relaxing activity for both sexes. In 2004, the world's first university dedicated to the principles of gastronomy, called the Université degli Studi di Scienze Gastronomiche, was founded in Bra, Piedmont (Italy). Its mission is to create an international research and education centre for those studying the link between food and culture. The importance of culinary tourism transcends its main function, which is to appease the physical need of food and begins to represent culture and a certain social status, and certainly in the years to come it will occupy an even more important and notorious place in the niche tourism market.

\section{Conceptual clarifications on the notion of gastronomic tourism}

An overview of food-based tourism can suggest that food and beverages have always been a part of the tourist experience. This is indeed real, but there is evidence that it was only from the beginning of the nineteenth century until the middle of the 20th century that food and drink became tourist products, with the appearance of restaurants, the establishment of criteria for the classification of culinary products categories of regional and national character, the appearance of cookbooks and coding of the preparation methods.

However, the number of tourists traveling only for the purpose of enjoying food and wine was very low in the middle of the 20th century, and this was not only due to the fact that gastronomic tourism was just beginning but also to transport costs. Thus, the organization of the first circuits and routes of wine in Germany, which began in the late 1920s, coincided with the increase in the number of car owners and the development of highways to and from major cities.

\section{The variety of definitions of gastronomic tourism}

Culinary tourism refers to journeys made in certain places, regions where local cuisine, including beverages, are the main motivation for travel. Today, the consumer is much better educated, has better physical condition, travels longer, lives longer and is concerned with his own health and the environment. As a result, food and drink have become more important and have priority for certain social groups. Food is the new cultural capital of the destination. One thing is certain: it has to be a quality product.

Generally, people choose to travel long distances on their journeys, to visit special places, to experience new and authentic experiences, and to get in touch with other civilizations and customs. A notable change in choosing the destinations by people 
traveling is the orientation towards places where they can get in touch with the local gourmet offer, where they can participate in culinary events or taste traditional recipes.

\section{Forms of gastronomic trips or travel with a gastronomic purpose}

In order to better understand the terms, we will briefly review them. Gourmet Tourism - In French means: 1) Wine tasting; 2) Very good at the field (connaisseur de bonne chère). In Romanian it is translated by the word "gourmand". Gourmet tourism is a form of tourism that has as its main and exclusive motivation the great interest in the field of food; for example, making a first-time trip to a particular restaurant, a specific market or a cellar. All or almost all activities during the journey are related to food / good eating.

"Cuisine" tourism in French has several meanings: 1) The place where food is prepared; 2) The art of preparing food; In the case of tourism, we translate into "Tourism for the Art of Food Preparation". It is a form of tourism that motivates a moderate interest in the field of food; for example, visiting local markets, festivals, restaurants and / or vineyards, among other activities carried out during the trip. Gastronomy was defined as "the art or science of eating well" (Gillepsie, 2001, p. 2). More generally, gastronomy is concerned with the appreciation, joy of enjoying, food and beverages, with a whole meal experience, offering the opportunity to learn about other cultures.

Urban / rural tourism - A type of tourism that is motivated by a low interest in the field of food; for example, visiting local markets, festivals, cellars or restaurants in semiurban and / or rural areas; these activities are considered "special attractions", and / or "attractions that must be seen".

Tourism and Travel (Stănciulescu, 2011, p. 272) - A form of tourism that motivates a low interest in the field of food; for example, visiting familiar restaurants during your trip or when dining outside your home.

As it results from the previous definitions, culinary culture has been influenced by the structural changes that have taken place in our society. Globalization, modernization, urbanization and migration have all modelled and transformed the way food is consumed by the modern civilization. Daily choices in food consumption are directly influenced by factors such as taste, cost, healthy lifestyle, satisfaction, convenience.

\section{Possible classification of "gourmet" tourists}

The type of behaviour of the traveller changes when they visit new destinations. They may want to try local and traditional dishes in the place 1or, on the contrary, they can choose to avoid dishes they are not familiar with.2 The second option may serve as an explanation for the frequency with which tourists choose to go to restaurants in international chains instead of experimenting with local products.

There are a number of ways that tourists interested in culinary tourism can be classified.

A first classification can be made according to the degree of interest shown to the food during a trip: (1) the gourmet tourist, (2) the enogastronomic tourist, (3) the gastronomic tourist, (4) the culinary tourism enthusiast, (5) the leisure tourist and (6) the tourist interested exclusively in tourism.

Gourmet and enogastronomic tourists are tourists who show a high interest in food and drink and travel exclusively in search of some culinary experiences. Gastronomic and culinary tourists give a moderate interest to meals during trips. This type of tourists combines activities related to eating with other types of activities within the travel program. Leisure tourists and those interested exclusively in the touristic part show a low interest in 
the traditional or specific dishes in the places visited. All activities related to eating or drinking are based on the simple fact that it is a physical necessity.

By making a second classification, we can distinguish four types of tourists:

Type I: gastronomy occupies a very important role in the vacations of this tourist, who constantly seeks information on the richness / gastronomic legacy of a certain area and the quality of the food in that area.

Type II: gastronomy is important, but the tourist needs access to information on culinary themes to act on them. The tourist does not show his interest as clearly as the type I, he does not seek information about the gastronomic offer specific to a destination, but has a positive reaction if he is confronted at the destination with the possibility to try new dishes or to be informed about local gastronomy.

Type III: Tourists do not attach importance to gastronomy as part of the holiday experience, but will do so if they have a good culinary experience during the holiday.

Type IV: Tourists are not interested in gastronomy and will continue to be disinterested, regardless of the quality or ingenuity of promotional materials for gourmet tourism.

A third classification is based on "The Bourdieu's Four Lifestyles Model" described by Hjalager (2004, pp. 195-201) in which culinary tourists are differentiated into: (1) recreational, (2) existential, (3) diversionists and (4) experimentalists. According to this classification, a recreational tourist has little incentive to try new things; this type of person does not like the changes in daily food consumption. At the opposite of this is the experimental tourist who is in a permanent search for new destinations and innovative menus. Culinary tourism enthusiasts are mentally motivated (1) - have the desire to discover new tastes or the joy of trying regional dishes, (2) cultural - they have the desire to learn about traditional dishes from a certain destination, (3) interpersonal desires - they use the meal as a means of socializing, (4) prestigious desires, such as the possibility for tourists to boast that they have visited a new in vogue restaurant.

\section{Manifestations and organizations dedicated to gastronomic tourism}

Culinary tourism manifestations are numerous and are becoming more and more popular, being invaded year after year by curious tourists who are eager to taste the gastronomic culture of other countries. Gourmet tourism surpasses the limits of picking up information from restaurant guides and menus, transcends dining at the restaurant.

Table 1. Examples of creating added value (according to Hjalager) in the south western England and north of Portugal

\begin{tabular}{|c|c|c|c|c|}
\hline Region & $\begin{array}{c}\text { Locally added } \\
\text { value }\end{array}$ & $\begin{array}{c}\text { Horizontally } \\
\text { added value }\end{array}$ & $\begin{array}{c}\text { Vertically added } \\
\text { value }\end{array}$ & $\begin{array}{c}\text { Diagonally added } \\
\text { value }\end{array}$ \\
\hline $\begin{array}{c}\text { South- } \\
\text { western } \\
\text { England }\end{array}$ & $\begin{array}{c}\text { Local production } \\
\text { guide }\end{array}$ & $\begin{array}{c}\text { Spreading the } \\
\text { gastronomy of } \\
\text { West Dorset, Trust } \\
\text { Land in agro } \\
\text { markets }\end{array}$ & $\begin{array}{c}\text { Agro food shops } \\
\text { and local } \\
\text { gastronomic routes }\end{array}$ & $\begin{array}{c}\text { Information and } \\
\text { training using the } \\
\text { internet }\end{array}$ \\
\hline $\begin{array}{c}\text { Northern } \\
\text { Portugal }\end{array}$ & $\begin{array}{c}\text { Specialized } \\
\text { producers }\end{array}$ & Certification & $\begin{array}{c}\text { Wine road, } \\
\text { gastronomic events }\end{array}$ & \\
\hline
\end{tabular}

Source: Anne-Mette Hjalager, Greg Richards, Tourism and Gastronomy, Ed. Routledge, 2011, p. 218.

The table shows that many of the initiatives are similar; however, an assessment of their relative success is more complex, because while the process is similar, the context differs. For example, there is a strong tradition and practice for festivals in northern Portugal, many of which - although they originated in religious festivals - also 
include an invariable gastronomic dimension. While this can be partly explained by the differences between a predominantly Catholic society opposed to predominantly Anglican-Presbyterian, these differences may well reflect even older traditions and cultures.

The culinary experience can involve visiting cooking schools and cookware stores, reading and collecting cookbooks, attending culinary tours, visiting guides of renowned chefs experts, consulting guides and menus, visiting wine cellars, distilleries, brasseries food producers, generally all culinary attractions. The following is a presentation of the events dedicated to this type of tourism.

Festivals are artistic festive events, periodically organized, where gastronomic achievements are presented. Two dimensions show the merits of a festival: the value of performances and its degree of individualization. Culinary festivals are especially dedicated to the particular culinary style of a region or to the preparation of dishes from a particular product. Culinary festivals attract more and more tourists animated by the curiosity of discovering new meals, traditions, places and people.

- Gourmet competitions and culinary shows have grown in popularity and numbers in recent years. There are many contests that challenge culinary creativity and many countries have integrated this activity into the promotional package of the various local areas.

- Culinary tourism also includes circuits at beer and culinary products factories, distilleries, vineyards and wine cellars, which attract curious tourists who want to know how the products they consume are manufactured.

- Cooking courses offered by renowned culinary schools, under the guidance of accredited cooks, are another special activity in the field of culinary tourism.

- Fairs, exhibitions and workshops dedicated to culinary tourism or the numerous culinary touristic circuits offered by tour operators or travel agencies.

In the last decades, culinary tourism has strengthened a well-defined position on the tourism market, a form of growing tourism. The increase in tourist clientele that prefers cultural visits to the detriment of other forms of tourism, the increasing independence of young people with a high culture and the increase in the number of foreign tourists in countries with remarkable cultural values show that there is a favourable flow for culinary tourism to exploit, track and amplify. In the ways of supporting and developing culinary tourism, seen as tourism of the future, an important role belongs to European and world organizations directly or indirectly involved in tourism.

Culinary tourism as an industry was not spoken of until 2001, when Erik Wolf, the president of the International Culinary Tourism Association (ICTA), distributed the White Book of Culinary Tourism. Even though scientific scholars have written about culinary tourism and wine tourism, before 2001 their works have been very rarely published and have not appeared in business magazines. Lucy Long, from Bowling Green University in Ohio, introduced for the first time the term "culinary tourism" in 1998. Then, in 2003, under the guidance of a group of counsellors, Erik Wolf founded the International Culinary Tourism Association, and in 2006 ICTA opened the International Culinary Tourism Institute. The International Culinary Tourism Association is considered the world authority with resources and information about food, drink and staff from the tourism industry all over the world. ICTA includes four major 
organizations: ICTA, ICTI, Association for International Culinary Tourism Development, International Association for Food Travel.

\section{Conclusions}

The tourist of the third millennium can also call himself a pilgrim and gourmet: a person who travels with the aim of discovering new treasures of a region where he can experience memorable and authentic experiences that he can later tell (pilgrim) and where he can share the pleasures of a good meals with locals, as a guest in their home or in their favourite gourmet venues. During a touristic journey, man continuously enlarges his horizons of knowledge. Travels give people the opportunity to enrich their minds and their souls, to love nature, to learn to appreciate the true value of the aesthetic treasures of the earth, to know the past and find out new things.

We observe that the diversity and gastronomic originality have acquired new valences, besides the proper physiological function, they have also started fulfilling some functions of recreation, relaxation, rest in general, of leisure.

The authorities in tourism around the world now recognize the potential of culinary tourism as a powerful tool capable of identifying and promoting places, regions or even entire countries. Global trends show that culinary tourists are looking for a more participatory style of holiday experiences to satisfy their interest in new foods and drinks which could contribute to their personal development and social status. Analysts have noticed a change in the behaviour of tourists, a shift from "passive observation" to "interaction and involvement," choosing to get in contact with locals and their way of life rather than being mere spectators.

Culinary tourism is an important and growing component in the big picture of the cultural tourism market. This unique form of tourism introduces tourists to a world of flavours, savour, and traditions associated with the preparation, serving and eating of food and drinks. As a contemporary cultural resource, gastronomy meets all the conventional requirements of a cultural tourism component. First, it is a viable alternative to destinations that cannot exploit the typical sun-sea-sand resources. Also, gastronomy adds value to touristic experience - on several levels - it is associated with quality tourism, it fits into the contemporary consumer consumption pattern, which is in constant search for new products and experiences that bring more satisfaction (Symons, 2002, p. 101).

The basic idea of culinary tourism is that food is also a touristic attraction alongside museums, monuments, landscapes or other defining elements that are part of the touristic sphere. In fact, statistics state that food accounts for $40 \%$ of the total satisfaction generated by the consumption of the tourist product. The tourist going out for gastronomic adventures desires to have memorable, rewarding experiences, and for this to happen, not only the luxurious many stars restaurants must be visited, but also the more withdrawn, less promoted ones that include the local essence, such as small cafes, pastries or bars known only by locals.

\section{Bibliography}

Brillat-Savarin, J., A.(2015). Fiziologia gustului. Bucureşti : BCC Publishing.

Gillespie, C. (2001). European Gastronomy into the 21st century. Oxford: Elsevier Butterworth-Heinemann.

Hall, C.M. \& Mitchell, R. (2005b). Gastronomy, food and wine tourism. In Buhalis \& Costa (eds), Tourism Business Frontiers: Consumers, Products and Industry. Oxford: Butterworth-Heinemann. 
Hjalager, A.M. (2004). Why do tourists eat and why? Towards a sociology of gastronomy and tourism. Revista Tourism: an international interdisciplinary journal, Volume 52(2), 195-201.

Hjalager, A.M., Greg Richards, G.(2011) Tourism and Gastronomy, Ed. Routledge

Raoult-Wack, A-L. (2007). Hrana. Spune-mi ce mănânci ca să-mi spui cine ești. București: Editura Univers.

Stănciulescu, G. (2011). Provocările turismului de nişă - turismul gastronomic şi oenologic. Oradea: Universitatea Oradea.

Symons M. (2002). Gastronomy as a tourist product: the perspective of gastronomy studies. U.K.: Routledge. 